\title{
QUANTITATIVE LEVELS OF C- REACTIVE PROTEIN IN CEREBROSPINAL FLUID IN CHILDREN WITH BACTERIAL AND OTHER MENINGITIS
}

Sharad Bansal ${ }^{1}$, Rimzim Gupta르 P.P. Gupta ${ }^{3}$, M. K. Kakkar ${ }^{4}$, A.K. Malhotra 5 .

1. M.D. Student, Department Of Pediatrics, Mahatma Gandhi Hospital \& Medical College,

2. Associate Professor, Department Of Pediatrics, Mahatma Gandhi Hospital \& Medical College,

3. Professor, Professor, Department Of Pediatrics, Mahatma Gandhi Hospital \& Medical College,

4. Associate Professor, Department Of Pediatrics, Mahatma Gandhi Hospital \& Medical College,

5. Professor \& HOD, Department Of Pediatrics, Mahatma Gandhi Hospital \& Medical College,

\section{CORRESPONDING AUTHOR: \\ Dr. Sharad Bansal, \\ P.G. Hostel, hospital campus, Jaipur. \\ E-mail: sharadpeds@gmail.com}

\section{HOW TO CITE THIS ARTICLE:}

Sharad Bansal, Rimzim Gupta, P.P. Gupta, M. K. Kakkar, A.K. Malhotra. "Quantitative levels of C- Reactive Protein in Cerebrospinal Fluid in Children with Bacterial and Other Meningitis". Journal of Evolution of Medical and Dental Sciences 2013; Vol2, Issue 25, June 24; Page: 4594-4598.

ABSTRACT: BACKGROUND: C-reactive protein rises rapidly in the first 24-48 hours of occurrence of bacterial meningitis and in large incremental increases thereafter. METHODS: All children (121) admitted during the period of study, with clinical suspicion of meningitis were clinically, biochemically, cytologically and bacteriologically investigated to clinch the diagnosis. Quantitative level of CSF was also sent for C-reactive protein assay by latex agglutination test by immunoturbidometric method. RESULTS: There were 121 cases of meningitis admitted in the hospital and only 10 cases were culture positive. There was significant difference of quantitative level of CSF CRP between bacterial and other than bacterial meningitis. CONCLUSION: Quantitative estimation of CRP in CSF by IMMUNOTURBIDIMETRY is a useful test to differentiate pyogenic meningitis from tubercular meningitis, viral meningoencephalitis and other non-meningitis CNS disorders. It is an easy, quick to perform, sensitive, reliable and rapid diagnostic test for timely therapeutic intervention. The detection of CRP in CSF also helps in the choice of appropriate antibiotic and the duration of therapy.

KEY WORDS: C-reactive protein, CSF, Meningitis, viral meningoencephalitis

INTRODUCTION: Meningitis is one of the most potentially serious infections occurring in infant and older children and important cause of morbidity and mortality in children worldwide. In the developing countries, acute bacterial meningitis (ABM) is one of the major cause of morbidity and mortality (1)Rapid and accurate diagnosis coupled with early appropriate therapy is the utmost importance in reducing morbidity and mortality of the patient Biochemistry, Cytology, Gram stain, Culture sensitivity of Cerebrospinal fluid usually being done to diagnose and differentiate pyogenic from aseptic meningitis. In such circumstances the detection of C-reactive protein (CRP) in CSF appears to provide a new dimension to the diagnosis of meningitis.(2) 
In developing countries, with limited resources, manpower, and skill, we need to think about an easy and comprehensive test by which we can diagnose ABM. Routine use of detection of CSF CRP, could be a reliable and easy to do test and can be done for rapid diagnosis of meningitis.

\section{OBJECTIVE:}

GENERAL OBJECTIVE: The study is aimed to estimate the level of CSF-CRP quantitatively in bacterial \& other meningitis in among children admitted in Pediatric department of the Mahatma Gandhi Medical College \& Hospital, Jaipur.

METHODOLOGY: Study design: The estimation of quantitative CSF-CRP among children of meningitis is a hospital based descriptive cross sectional study.

Place of study: All aspects of this study have been accomplished in the department of Pediatrics, of the Mahatma Gandhi Medical College \& Hospital, Jaipur.

Period of Study: The study was done in a period of 15 months from October 2011 to December 2012.

Sample Size: Total patients were 121.

Inclusion Criteria: Infant and children of ages 1 day to 14 years diagnosed case of meningitis, who required a CSF study to confirm or exclude the diagnosis.

Exclusion criteria: Congenital anomalies of CNS, Non infectious conditions of CNS , Infections at the site of lumbar puncture.

Method of CSF-CRP was quantitatively detected by immuno-turbidimetry method by using Biosystems CRP kit.

121 patients of meningoencephalitis, between 1 day to 14 years of age were included in the study and were divided in 4 groups:- Group I- Pyogenic meningitis, Group II- Tubercular meningitis, Group III-Viral meningitis and Group IV- No CNS infection (Extra cranial infections).

RESULTS: There were 53 cases of bacterial meningitis, 27 cases of viral meningoencephalitis, 13 cases of tubercular meningitis and 28 cases of control group. The male female ratio in the Acute Bacterial Meningitis, Tubercular Bacterial Meningitis, Viral Meningocephalitis and Control Group were 1.94:1, 5.5:1, 1.7:1 and 1.33:1 respectively. All groups were with male predominance.

Table no-1: Distribution according to sex \& diagnosis of patients

\begin{tabular}{|l|l|l|l|}
\hline \multirow{2}{*}{ Diagnosis } & \multicolumn{2}{|l|}{ Sex } & Total \\
& Male n (\%) & Female n (\%) & $\mathbf{n}(\%)$ \\
\hline \multirow{2}{*}{ Acute Bacterial Meningitis } & 35 & 18 & 53 \\
& $(66.03)$ & $(33.97)$ & $(100.00)$ \\
\hline \multirow{2}{*}{ Tubercular Bacterial Meningitis } & 11 & 2 & 13 \\
& $(84.62)$ & $(15.38)$ & $(100.00)$ \\
\hline \multirow{2}{*}{ Viral Meningocephalitis } & 17 & 10 & 27 \\
& $(62.97)$ & $(37.03)$ & $(100.00)$ \\
\hline \multirow{2}{*}{ Control Group } & 16 & 12 & 28 \\
& $(57.15)$ & $(42.85)$ & $(100.00)$ \\
\hline Total & 79 & 42 & 121 \\
& $(65.29)$ & $(34.71)$ & $(100.00)$ \\
\hline
\end{tabular}


In present study, the total 53 cases of pyogenic meningitis, $18(33.96 \%)$ were in the age group of <1year, $12(22.64 \%)$ were in the age group of $1-5$ years and 23 (43.39\%) were in the age group of 5-14 years. CSF- culture was positive only 10 cases of bacterial meningitis while all other cases of all groups were culture negative.

In our study, $47(88.67 \%)$ cases out of 53 had quantitative level of CSF-CRP $>1000 \mathrm{ng} / \mathrm{ml}$ in bacterial meningitis patients and only $6(11.32 \%)$ cases had $<1000 \mathrm{ng} / \mathrm{ml}$. 19 cases (35.84\%) had $>2000 \mathrm{ng} / \mathrm{ml}$ level of CSF-CRP in this group. In tubercular meningitis patients $11(84.61 \%)$ of $13 \mathrm{had}$ $<1000 \mathrm{ng} / \mathrm{ml}$ quantitative level of CSF-CRP and only two had $>1000 \mathrm{ng} / \mathrm{ml}$ CSF-CRP. In viral meningoencephalitis group CSF-CRP was $>1000 \mathrm{ng} / \mathrm{ml}$ in 5 cases of 27 and rest 22 cases had < $1000 \mathrm{ng} / \mathrm{ml}$ quantitative level of CSF-CRP.

Table no-2 Distribution according to CSF CRP level \& diagnosis of patients

\begin{tabular}{|c|c|c|c|c|c|}
\hline \multirow{2}{*}{$\begin{array}{l}\text { CRP } \\
(\mathrm{ng} / \mathrm{ml})\end{array}$} & \multicolumn{4}{|l|}{ Diagnosis } & \multirow[b]{2}{*}{ Total n (\%) } \\
\hline & $A B M n(\%)$ & TBM n(\%) & VME n(\%) & $\begin{array}{l}\text { Control } \\
\text { Group n (\%) }\end{array}$ & \\
\hline$<1000$ & $\begin{array}{l}6 \\
(11.32)\end{array}$ & $\begin{array}{l}11 \\
(84.61)\end{array}$ & $\begin{array}{l}22 \\
(81.48)\end{array}$ & $\begin{array}{l}25 \\
(89.28)\end{array}$ & $\begin{array}{l}64 \\
(52.89) \\
\end{array}$ \\
\hline $1000-2000$ & $\begin{array}{l}28 \\
(52.83)\end{array}$ & $\begin{array}{l}2 \\
(15.38)\end{array}$ & $\begin{array}{l}5 \\
(18.51)\end{array}$ & $\begin{array}{l}3 \\
(10.71)\end{array}$ & $\begin{array}{l}38 \\
(31.40)\end{array}$ \\
\hline$>2000$ & $\begin{array}{l}19 \\
(35.84)\end{array}$ & $\begin{array}{l}0 \\
(0.00)\end{array}$ & $\begin{array}{l}0 \\
(0.00)\end{array}$ & $\begin{array}{l}0 \\
(0.00)\end{array}$ & $\begin{array}{l}19 \\
(15.70)\end{array}$ \\
\hline Total & $\begin{array}{l}53 \\
(100.00)\end{array}$ & $\begin{array}{l}13 \\
(100.00)\end{array}$ & $\begin{array}{l}27 \\
(100.00)\end{array}$ & $\begin{array}{l}28 \\
(100.00)\end{array}$ & $\begin{array}{l}121 \\
(100.00)\end{array}$ \\
\hline
\end{tabular}

The mean CSF CRP was $1862 \mathrm{ng} / \mathrm{ml}$ in bacterial meningitis while it was $597 \mathrm{ng} / \mathrm{ml}$ in control group and was $992 \mathrm{ng} / \mathrm{ml}$ and $816 \mathrm{ng} / \mathrm{ml}$ in viral meningoencephalitis \& tubercular bacterial meningitis respectively. The difference in CSF CRP between bacterial and all other groups was highly significant.(table3)

Table no-3 Mean \pm SD of CSF CRP according to diagnosis of subjects

\begin{tabular}{|l|l|l|}
\hline Diagnosis & No. & $\begin{array}{l}\text { Mean } \mathbf{~ S D ~} \\
\mathbf{n g} / \mathbf{m l}\end{array}$ \\
\hline ABM & 53 & $1862.20 \pm 812.19$ \\
\hline TBM & 13 & $816.00 \pm 361.55$ \\
\hline VME & 27 & $992.00 \pm 462.92$ \\
\hline Control Group & 28 & $597.20 \pm 301.38$ \\
\hline
\end{tabular}

\begin{tabular}{|l|l|l|l|l|l|}
\hline $\begin{array}{l}\text { Control Group } \\
\text { v/s ABM }\end{array}$ & $\mathrm{p}<0.001$ & $\begin{array}{l}\text { Highly } \\
\text { Significant }\end{array}$ & ABM v/s TBM & $\mathrm{p}<0.001$ & $\begin{array}{l}\text { Highly } \\
\text { Significant }\end{array}$ \\
\hline $\begin{array}{l}\text { Control Group } \\
\text { v/s VME }\end{array}$ & $\mathrm{p}<0.01$ & Significant & $\begin{array}{l}\text { Control Group v/s } \\
\text { TBM }\end{array}$ & $\mathrm{p}<0.001$ & $\begin{array}{l}\text { Highly } \\
\text { Significant }\end{array}$ \\
\hline ABM v/s VME & $\mathrm{p}<0.01$ & Significant & TBM v/s VME & $\mathrm{p}>0.05$ & $\begin{array}{l}\text { Not } \\
\text { Significant }\end{array}$ \\
\hline
\end{tabular}


DISCUSSION: Bacterial meningitis is a potentially devastating illness. So prompt recognition and early appropriate treatment is essential. Males are more affected in pyogenic (66\%) meningitis.

In the present study Gram's smear and CSF culture for pyogenic organism could detect only $24 \%$ and $20 \%$ cases respectively.

In our study IMMUNOTURBIDIMETRY method was used for quantitative analysis of CRP in CSF by using Biosystems CRP kit to detect CRP in CSF of suspected cases of meningitis. We studied the utility of CRP in the differential diagnosis of meningitis of varying etiology.

Our analysis showed the quantitative value of CSF CRP was significantly higher in bacterial meningitis group. The difference between pyogenic meningitis and control group $(\mathrm{p}<0.001)$, between pyogenic meningitis and viral meningo encephalitis $(\mathrm{p}<0.001)$ and between pyogenic meningitis and tubercular meningitis were highly significant $(\mathrm{p}<0.001)$. The difference between tubercular meningitis and control group and between viral meningo-encephalitis and control group were significant $(\mathrm{p}<0.05)$.While the difference between tubercular meningitis and viral meningoencephalitis was not significant $(\mathrm{p}>0.05)$. These findings were similar with other study findings like Donald PR et al, Gray BM et al, Hanson LO et al, Trienekens PH et al, Shimetani N et al, Belal M et al (3-8).

CONCLUSION: Although culture of CSF is the gold standard for diagnosis of pyogenic meningitis for direct evidence of the organism, it has some limitation particularly in peripheral set up. Routine use of detection of CSF-C-reactive protein could be a reliable, rapid and easy to do test for the diagnosis of bacterial meningitis and differentiate from aseptic meningitis. It is not an alternative of examination of CSF biochemistry, cytology and culture.

CONTRIBUTORS: Designed by SB \& AKM. SB \& PPG: retrieved information from case records, collected \& analyzed the data; MKK \& RG: provided analytic input \& guided in analysis \& review of literature; all authors contributed to the preparation of the manuscript, provided significant inputs during preparation for final publication \& approved the final manuscript. AKM: supervised the study \& shall be its guarantor.

\section{BIBLIOGRAPHY:}

1. Murray CJ and Lopez AD. Global Burden of Disease and Injury Series Global Health Statistics. World Health Organization, Geneva, 1996; 11. 285.

2. Pemde HK, Harish K. C-reactive protein in Childhood Meningitis. Indian J. Pediatr 1996; 63: 73-77.

3. Donald PR, Starchan AF, Schaeman JF, Beer FCD. Cerebrospinal fluid C-reactive protein in infective meningitis in childhood. J Lab Clin Med. 1985; 106: 424-427.

4. Gray BM, Simmons DR, Mason H, Barnum S, Volanakis JE. Quantitative levels of C-reactive protein in cerebrospinal fluid in patients with bacterial meningitis and other condition. J Pediatrics. 1986; 108 (1): 665-670.

5. Hanson LO, Lindquist L, Linne T, Sogo E. Quantitation of C-reactive protein in cerebrospinal fluid and serum by zone immunoelectrophoresis assay. J Immunological Methods. 1987, 26; 100(1-2): 191-195. 


\section{ORIGINAL ARTICLE}

6. Trienekens PH, Willams FTC. Significance of C-reactive protein in spinal fluid. Clin Chem 1985; 31(2):345.

7. Shimetani N, Shimetani K, Mori M. Level of three inflammation markers, C-reactive protein, serum amyloid A protein and procalcitonin, in the serum and CSF of patients with meningitis. Scand J Clin Lab Invest. 2001; 61(7):567-74.

8. M Belal Uddin, Manjira Rahman, Siddique A B. Usefulness of CSF C-Reactive Protein in differentiating Pyogenic and Aseptic Meningitis. TAJ 2009; 22(1): 78-81. 